\title{
THE MULTIPLIER EFFECT OF BALINESE LABOR WORKING ON CRUISE SHIP
}

\author{
I Made Darma Oka. \\ Politeknik Negeri Bali \\ madedarmaoka@pnb.ac.id
}

\begin{abstract}
As one of the most popular destinations for international tourists, Bali has attracted a sizeable and growing labor force in the tourism sector of the economy. This fact has triggered Balinese labor force to participate in such a service industry. As a supplier of tourism labor force Bali has been increasingly successful in promoting the number of workers to be employed in cruise tourism industry. The participation rate of Balinese labor in cruise tourism industry over the last years has dramatically increased. The growth of Balinese labor who works on cruise ships in the past four years reached more than 18 percent. It is happening because they have been prepared themselves in accordance to the competencies and qualifications needed in cruise tourism industry. The Balinese labor's participation in cruise tourism industry employment has brought major implications for their life and culture. The present study aimed to analyze the multiplier effect of Balinese labor works in cruise tourism industry overview from economic and socio-cultural perspective. The research subjects were Balinese labor who used to or were still working in the cruise tourism industry. This research used qualitative data. The collected data started from one Balinese labor having experience in the cruise tourism industry and then spread to the other workers. To answer the research questions, data collection was conducted through observation and deep interviews. The data were analyzed by qualitative analysis. In analyzing the data of economic and sociocultural perspective of Balinese labor who work in the cruise tourism industry in the environment of life, it was done through the processing and interpretation of the data which is a series of periodic review, grouping, systematization, interpretation and reification of data so that a phenomenon has social academic and scientific value. The data analysis was conducted to find the hidden reasons behind the actions of the perpetrators of social action or geared towards social significance of social phenomena. The focus is to find what kind of mindset that glows behind a social phenomenon or to find the rationality that lies behind the social phenomena. The multiplier effect of Balinese labor working in cruise tourism industry was overviewed from economic and socio-cultural perspectives. The economic perspective likes: Balinese labor working on cruise ship able to improve the family economy, and employment for the community directly or indirectly in the cruise tourism industry. The socio-cultural
\end{abstract}

Journal of Business on Hospitality and Tourism 
perspective likes: by working on cruise ships able to motivate the other Balinese labor to works on cruise ships, with working on cruise ships can open the horizons and the way of thinking society, increase the personal discipline, make clean and healthy in their live, and then improve the science and technology in tourism especially at cruises, able to strengthen the unity of nation, anticipation for disintegration, and growth the awareness to conserve the cultural after seeing the variety of cultures in the word. Based on the conclusions above, the following suggestion can be made: the government should pay attention to the existence of Balinese labor, who work in cruise ships, to the protection of their rights as well as the relevant acts should be made clear, knowing that they serve as ambassadors of the nation that generate income for the country; and the government should provide support to Balinese laborers in accordance with their potential

Keywords: Multiplier effect, Balinese labor, cruise tourism industry

\section{INTRODUCTION}

Bali labor force working in the cruise tourism industry in the last five years has grown drastically. The growth of Balinese labor who works in the cruise ship tourism industry reached more than $18 \%$ (BP3TKI, 2015). The open access of Balinese labor to working on cruise ships, as well as the increasing needs in life can motivate the Balinese workforce to try their luck for success through working on cruise ships.

Empowerment of Balinese labor to work on cruise ships still need to be increased, by making use of all the potentials in an attempt to seize job opportunities in cruise ships. The goal is that the labor Bali both men and women can contribute ideas and energy in the development of tourism. The development of tourism is very complex and involves all relevant stakeholders. Active role involvement of stakeholders aims to provide optimum benefits for generations to come. Related to this, Alavalapati and Adamowicz (2000) mention the need to balance between the benefits of the development model of economy, environment, and community empowerment in tourism development. Reid et.al (2004) state in tourism activities, need broad and conscious participation of all those involved in tourism activities, from the planning stages to implementations. Gelbman and Timothy (2011) suggest physical, social, and cultural elements are a potential element to be considered in the development of tourism to be sustainable. Furthermore Nunkoo et.al (2012) mentions that the perception of the economy, the attitude of the political institutions, the potential of the local community, and the belief in the individuals is important in the development of the tourism industry so that tourism activities are sustainable.

It is recognized that the empowerment of Balinese labor on a cruise ship can give a multiplier effect on their life such as being able to help increase family's income, and the surrounding environment, adding international experience, conversely working on cruise ships may also cause negative implications. Therefore, in the empowerment of Balinese labor on a cruise ship 
that is managed professionally so as to minimize the negative implications that may arise.

\section{RESEARCH METHODS}

This study used qualitative data. In collecting data on multiplier-effects of Balinese labor working on cruise ships, the informants were sought with an unspecified amount. Data collections started from one of the Balinese workers who already had work experience in the cruise tourism industry and then spread to the other workers. The gathered data were considered sufficient after the information or the data obtained were saturated. The analysis of the data used was qualitative analysis, through the processing and interpretation of the data, which were a series of reviews, grouping, systematization, interpretation and reification of data so that a phenomenon has a social value, academic and scientific value. The focus was to find what kind of mindset that glowed behind a social phenomenon or to find rationality that lies behind the social phenomenon (Bungin, 2011: 45).

\section{DISCUSSION}

Balinese people in general are still unfamiliar with the activity of workers who work in the cruise tourism industry. The community still views that people working in cruise ships certainly wallow in wealth. Public opinion like that is not entirely true. Balinese labor who has worked in cruise tourism industry realizes that by working on a cruise ship, they can earn more money than working in the country, but that does not mean the money they earn comes by itself without hard work. Balinese labor force working on a cruise states that they are working on a cruise ship with an average of 10-12 hours per day.

This is confirmed by I Wayan Wiarta (former employees having worked in cruise ship for 15 years) states that: "The labor's income while working on a cruise ship is higher than working in the country in the same field but with hours of work more than 10 hours per day". It is also said in the employment contracts signed by workers it is mentioned that all workers are required to work for 10 hours per day. But in reality, they often work doing their obligations for 12 hours per day. Any workers who work on cruise ships working full time for seven days a week without a day off, except that he or she is sick". Revenues earned by Balinese labor are noticeably higher when taken home or sent to Bali. This statement indicates that the Balinese labor is very aware of how difficult it is to make money on cruises, so they are really trying to optimally manage the money that has been obtained for the future.

The hard work done by Balinese labor working on cruise ships is realized to have the dual benefit (multiplier effect) to him/her, family, neighborhood, or country. The struggle that they do is to get money in order to be able to increase the welfare or the family economy. Struggle of the Balinese labor is very precious because they are struggling not only to develop their own interests, such as helping families to improve the economy of the family but also for the wider interest that is for the betterment of the nation. This is in line with research by Sunarsa (2011) which states that the primary purpose of Balinese labor working on a cruise is to get as much money in an effort to improve the economic situation of the family. This is in line with the theory of needs by Maslow (1943) stating 
that the motivation of the Balinese workforce to work in cruise ships is still dominant in the level / degree of physiological needs. Explicitly, the primary purpose of Balinese labor to work on cruise ships is increasing the family's income.

Family economic improvement was perceived very well by the married couple I Komang Manis (58) and Ni Made Sarwini (56), the parents of Ni Putu Ardyanti, in an interview at his home (Jl. Majapahit, Tabanan). Komang Manis stated that "as a retired lower class civil servant as well as the wife just being a housewife, it is very difficult to be able to repair the house let alone to buy a land". But thanks to his son Putu Ardyanti repeatedly (10 times) working on a cruise ship, his family life increased dramatically. Initially he (Komang Manis) did his child's financial management with the child's permission to be used in repairing the merajan (the place of worship of the family), the renovation of houses, and further investment of several land assets in Tabanan. It was also said to date that his son Putu Ardyanti had been able to buy two houses, four plots of land, as well as the first agricultural land area of 1.2 hectares in Tabanan. The land assets has been built partly as a boarding house intended for people who need it so that it can make money every month to make ends meet. Furthermore the user I Kadek Hendra Juli Hartawan, (former cruise ship worker) is now a director and also the owner of PPTKIS Bali Paradise Citra Dewata (BPC), a labor supply of cruise companies to Europe. Until now PPTKIS BPC still exists in recruiting people to cruise ships, to meet user demand for cruise ship foreign labor's need which is always increasing, to open up greater access for workers to work on a cruise ship.

Kadek Ayu Tika Sari (former cruise ship worker for 6 years) revealed that "the income of Balinese workers on a cruise ship can be divided into two categories, namely tipping crew positions and non-tipping crew positions. Nontipping position is such positions as galley, cook, administration, accounting, while the tipping position is waitress, housemaid, stateroom, or stewardess". This indicates that the informant expression is basically the income of workers who work on cruise ships can be divided into two categories namely tipping position non-tipping crew and crew position. For non-tipping position like galley, cook, administration, accounting, they obtain adequate fixed salary of the cruise ship companies. For tipping position as women waitress, housemaid, and stateroom stewardess earn minimal income which is over 375 dollars per month. Employees who earn from tipping system are employees who derive their income from tips by guests for services provided while employees with non-tipping system are the employees who receive a steady income from the company.

Income workers who work in the tourism industry cruise ships actually came more from fees (tips) given by the guests, be it direct or indirect tips. Total normal income that can be obtained is between 1,000-2,500 US dollars per month, depending on the position and the number of guests who pay fees. If the earnings of women are less than that amount, it may be caused by the fact that not all guests served are willing to pay tips, or perhaps because of the number of guests served is less than it should be, or the cruise ship is being in a state of low season. Conversely, if a labor income is higher, this can be caused by the fact that all the guests served pay tips and still give direct tips for guests were satisfied with the services provided. This is confirmed by Hartono (2012: 79) who states that at the 
level of crew is able to obtain employment income between 1,200 and 2,500 US dollars per month depending on the position as well as a cruise ship where the labor works. Based on informant information above, it can be said that through work on cruise ships, Balinese labor either directly or indirectly improves the economy of the family, local community, state and the nation; opening job and business opportunities for the people associated with tourism activities.

In a socio-cultural perspective, Balinese labor mentioned that working in the cruise tourism industry is exciting. They are proud to be working on a cruise ship as they get a chance to be able to see other countries that previously might have never been imagined in their minds to visit. The countries they visit are countries that have a unique social life much different from the Balinese social system. It is a delight to Balinese workers because previously they had never imagined having a trip to those countries. But behind the fun, there is also a barrier for the crew in their daily interactions with guests and fellow crew. This has to do with communication in international language, i.e. English. Workers who work in a cruise ship company come from different nations, languages, and cultures. Every worker on cruise ships is required to communicate using English in the living area / guest area. It can spur the Balinese labor to learn more seriously, so the ability to adapt to the working environment would be better. Their social interactions that occur on cruise ships are proven to motivate the Balinese workforce to learn and improve communication skills in English so that they can exist in the eyes of colleagues. This is an application of the theory of needs by Maslow (1943) level 3 and 4, namely social needs and the need for prestige (esteem needs). Because humans are social beings then of course they have social needs, such as the need for feeling accepted by others in which they live and work so that the status and prestige get higher. In view of the social paradigm, the social reality is the result of human creation through the power of social construction of the social world around them. Bungin (2011:4) states that social reality "exists" viewed from subjectivity "exists" itself and the objective world around social reality. Individuals are not only seen as "their existence" but also seen from where "the existence" is present, how he received and actualize himself and how environment accepts it.

Social problems such as "alcohol, gambling and women" are often identified with the workers who work in cruise ships. These three things are often identified with the workers who work in cruise ships by some people. Actually, this view is a view that is not entirely true and needs to be clarified or deconstructed, because not all of the individual workers who work in cruise ships do a thing like that. This is in line with the statement by Derrida (in Lubis, 2006: 103) which states that through deconstruction, we are looking for a basic truth in accordance with the circumstances that happen in people's lives, especially for workers in cruise ships.

I Wayan Wiryasuta a former cruise ship worker who has had experience working in a cruise ship for 13 years states that "cultural and social problems" are things that need serious attention so that the Balinese workers working in cruise tourism industry can anticipate them in an early stage". This informant impression emphasizes the importance of preventive action against Balinese labor working on cruise ships in order not to be involved in social issues. Furthermore, it is said Balinese workers working on a cruise ship feel far from family circles, friends and 
homeland, sometimes making them feel free because no one's watching. Such conditions often make Balinese labor out of control so it can get stuck in activities that are not appropriately carried out. This is in line with the opinion of Bungin (2011: 3) which says that humans in many ways have the freedom to act outside the control limits structures and social institutions where people are coming from. Humans actively and creatively develop themselves through the responses to the stimulus in the cognitive world. Therefore social processes experienced by each individual man can change the social reality in an environment where they are located. Success in anticipating such temptation has been able to be put into evidence by Balinese labor working in the cruise tourism industry. His life has now changed to increase both economically and socially "social status" of society, as expressed by Ni Komang Diah Sekarsari. She stated that "with work experience in cruise ship, he felt proud because he felt more appreciated and respected in the association both in the family and in the community. He also said to feel safe and comfortable working on cruise ships due to the support of the family. Temptation problems happen in cruise ships all depend on us to respond to them". The impression delivered by Komang Diah Sekarsari is not exaggerated and indeed it is a reality that is happening in the community. In a community association in his village, he now felt more appreciated by his peers. Prior to working on cruise ships, she was often ostracized by her friends, not to get along just how it should be because of the economic situation of the family is still minimal. But after she repeatedly sets off and works on cruise ships, now friends actually do otherwise change 180 degrees. This reality is one of the motivations of Komang Diah Sekarsari to decide to work in a cruise tourism industry in order to prove to her friends that she is also capable of changing the status of herself and her families. This is in line with the theory of needs by Maslow (1943) level four having to do with esteem or status needs, namely the need for self-respect, acceptance and appreciation of the community environment. Recognition status is manifested by a status symbol that has risen from a modest innocent country girl into an internationally-minded country girl. The success of the workforce is able to motivate other Balinese to work on cruise ships so as to change the thought patterns of society to move forward, educate clean and healthy disciplined way of life, and to improve science and technology in the field of tourism, especially cruise ships. After watching various world cultures, workers are able to raise awareness in strengthening the unity of the nation, in anticipation of disintegration, and raise awareness to preserve their own culture.

\section{CONCLUSIONS AND SUGGESTIONS}

The multiplier effect of Balinese labor working in a cruise ship on his life is most easily seen in the perspective of economics. Balinese labor force working in cruise ships is proven to help families to improve the economy of family, neighborhood, and nation. In a socio-cultural perspective of workers who work on cruise ships are able to improve the social status / prestige and family, as well as being capable of transmitting knowledge and experience with other workers so as to motivate them to go to work on a cruise ship. After watching various world cultures visited, they are able to raise awareness in strengthening the unity of the nation, in anticipation of disintegration, as well as raise awareness to preserve the culture. It is suggested that the government should provide wider access to the 
Balinese labor interested in working in cruise ships, as well as providing education and training on a regular basis to poor families so that they also have the same opportunity to get a job in a cruise ship.

\section{ACKNOWLEDGMENTS}

We express our gratitude to the informants who helped us with information and data necessary. Our gratitude also goes to all other parties that have supported the writing of this article.

\section{REFERENCES}

Alavalapati, J. R. R. dan W. L. Adamowicz. 2000. Tourism Impact Modelling for Resource Extaction Regions. Annals of Tourism Research. 27 (1), 188-202.

Balai Pelayanan Penempatan dan Perlindungan Tenaga Kerja Indonesia (BP3TKI). 2015. Penempatan TKI Tahun 2014. Denpasar.

Bungin, B. 2011. Metode Penelitian Kualitatif. Aktualisasi Metodologis ke Arah Ragam Varian Kontemporer. Jakarta: PT. Raja Grafindo Persada.

Gelbman, A., Timothy, D. J. 2011. Border Complexity, Tourism and International Exclaves; A Case Study. Annals of Tourism Research. 38 (1), 110-131.

Hartono, S. 2012. Bekerja di Kapal Pesiar "Panduan Praktis Mengawali Karier di Kapal Pesiar" Solo: Cet. 1.

Lubis, A. Y. 2006. Dekonstruksi Epistemologi Modern: Dari Postmodernisme, Teori Kritis, Poskolonialisme Hingga, Cultural Studies. Jakarta: Pustaka Indonesia Satu.

Maslow, A. H. 1943. A Theory of Human Motivation. Psychological Review. 50, 370-396.

Nunkoo, R., Ramkissoon, H., and Gursoy, D. 2012. Public Trust in Tourism Institutions. Annals of Tourism Research. 39 (3), 1538-1564

Reid, D. G., H. Mair, W. George, 2004. Community Tourism Planning: A SelfAssesment Instrument. Annals of Tourism Research. 31 (3), 623-639. 